\title{
EDUKASI KESEHATAN DIABETES MELLITUS DI RW.004 KELURAHAN BENDA BARU KOTA TANGERANG SELATAN
}

\section{DIABETES MELLITUS HEALTH EDUCATION IN RW 004 BENDA BARU VILLAGE SOUTH TANGERANG CITY}

\author{
${ }^{1)}$ Noor Latifah Amin ${ }^{*}{ }^{2)}$ Dadang Herdiansyah, ${ }^{3)}$ Annisa Aulia Nasyithoh \\ ${ }^{1,2,3)}$ Program Studi Kesehatan Masyarakat, Fakultas Kesehatan Masyarakat \\ Universitas Muhammadiyah Jakarta \\ Alamat: Jl. K.H. Ahmad Dahlan, Cirendeu, Ciputat, Tangerang Selatan \\ "Email: tiefa85@gmail.com
}

\begin{abstract}
ABSTRAK
Penyakit Diabetes Mellitus (DM) merupakan salah satu penyakit PTM penyebab kematian utama di Indonesia. Jika dibandingkan dengan tahun 2013, prevalensi Diabetes Mellitus berdasarkan diagnosis dokter pada penduduk usia $\geq 15$ tahun hasil Riskesdas 2018 meningkat 2\%. Pada tahun 2018 berdasarkan data Puskesmas Benda Baru diketahui bahwa penyakit Diabetes Mellitus merupakan peringkat kedua dari 10 besar penyakit yang diderita oleh warga di sekitar kelurahan Benda Baru. Tujuan dari kegiatan Pengabdian Kepada Masyarakat adalah untuk meningkatkan pengetahuan warga pada usia> 15 tahun mengenai penyakit Diabetes Mellitus melalui penyuluhan kesehatan. Metode yang digunakan dalam penyuluhan adalah ceramah dan diskusi, selain itu untuk melihat peningkatan pengetahuan warga dilakukan pre dan post test serta hasilnya akan dianalisis dengan uji $t$-dependent. Penyuluhan kesehatan dilakukan pada tanggal 09 Februari 2020 dengan sasarannya adalah warga RW 004 Kelurahan Benda Baru. Pada kegiatan penyuluhan kesehatan diperoleh hasil yaitu meningkatnya pengetahuan warga secara signifikan dalam mencegah Diabetes Mellitus dan mengendalikan gula darah. Selain penyuluhan kesehatan, dilakukan pengenalan media untuk mengontrol GGL (Gula, Garam, dan Lemak) berupa kalender KLG2 (Kontrol Lemak, Gula, dan Garam) dan kegiatan olahraga berupa senam aerobic. Pelayanan kesehatan yaitu Puskesmas Benda Baru diharapkan untuk aktif dalam memberikan edukasi secara berkala mengenai Diabetes Mellitus dan aktif menggerakkan program kesehatan lainnya bersama masyarakat untuk mencegah Diabetes Mellitus dan mengendalikan gula darah.
\end{abstract}

Kata Kunci : Diabetes Mellitus, Gula Darah, Penyakit Tidak Menular

\section{ABSTRACT}

Diabetes Mellitus (DM) is a non-communicable disease which is the main cause of death in Indonesia. When compared with 2013, the prevalence of Diabetes Mellitus based on the diagnosis of doctors in the population aged $\geq 15$ years the results of Riskesdas 2018 increased by 2\%. In 2018, based on data from Benda Baru Public Health Center, it was found that Diabetes Mellitus was ranked second out of the top 10 diseases suffered by residents around Benda Baru village. The purpose of Community Service activities is to increase the knowledge of citizens aged $>15$ years about Diabetes Mellitus through health education.The method used in counseling is lectures and discussions, in addition to seeing an increase in citizen knowledge carried out pre and post test and the results will be analyzed by t-dependent test. Health education was carried out on February 9, 2020 with the target being RW 004 residents of Benda Baru Village. In the health counseling activity, the results obtained were significantly increased knowledge of citizens in preventing diabetes and controlling blood sugar. In addition to health education, media are introduced to control SSF (Sugar, Salt and Fat) in the form of the FS2C calendar (Fat, Sugar and Salt Control) and sports activities in the form of aerobics. Health services namely the Benda Baru Health Center are expected to be active in providing regular education about Diabetes Mellitus and actively activating other health programs with the community to prevent Diabetes Mellitus and control blood sugar.

Keyword: Diabetes Mellitus, Blood Sugar, Non-Communicable Disease 


\section{PENDAHULUAN}

Penyakit Tidak Menular (PTM) saat ini telah menjadi ancaman serius kesehatan global, salah satu diantara PTM tersebut adalah Diabetes Mellitus (Kemenkes RI, 2018).73\% kematian saat ini disebabkan oleh penyakit tidak menular, 35\% diantaranya karena penyakit jantung dan pembuluh darah, $12 \%$ oleh penyakit kanker, $6 \%$ oleh penyakit pernapasan kronis, 6\% karena diabetes, dan 15\% disebabkan oleh PTM lainnya (WHO, 2018). Hasil Survei Kesehatan Rumah Tangga (SKRT) 1995-2001 dan Riskesdas 2007 menunjukkan bahwa penyakit tidak menular seperti stroke, hipertensi, diabetes melitus, tumor, dan penyakit jantung merupakanpenyebab kematian utama di Indonesia. Pada tahun 2007, sebesar $59,5 \%$ penyebab kematian di Indonesiamerupakan penyakit tidak menular. Selain itu, persentase kematian akibat penyakit tidak menular juga meningkat dari tahun ke tahun, yaitu 41,7\% pada tahun 1995 , 49,9\% pada tahun 2001, dan 59,5\% pada tahun 2007. Riskesdas tahun 2018 menunjukkan bahwa terjadi peningkatan pada indikator-indikator kunci PTM yang tercantum dalam RPJMN 2015-2019, sebagai berikut : 1. Prevalensi tekanan darah tinggi pada penduduk usia 18 tahun keatas meningkat dari $25,8 \%$ menjadi $34,1 \%$; 2 . Prevalensi obesitas penduduk usia 18 tahun ke atas meningkat dari 14,8 \% menjadi $21,8 \%$; 3 . Prevalensi merokok penduduk usia $\leq 18$ tahun meningkat dari $7,2 \%$ menjadi $9,1 \%$ (Kemenkes, 2018).

Diabetes adalah penyakit kronis serius yang terjadi karena pankreas tidak menghasilkan cukup insulin (hormon yang mengatur gula darah atau glukosa), atau ketika tubuh tidak dapat secara efektif menggunakan insulin yang dihasilkannya. Diabetes adalah masalah kesehatan masyarakat yang penting, menjadi salah satu dari empat penyakit tidak menular prioritas yang menjadi target tindak lanjut oleh para pemimpin dunia. Jumlah kasus dan prevalensi Diabetes terus meningkat selama beberapa dekade terakhir (WHO Global Report, 2016). Diabetes menyebabkan 1,5 juta kematian pada tahun 2012. Gula darah yang lebih tinggi dari batas maksimum mengakibatkan tambahan 2,2 juta kematian, dengan meningkatkan risiko penyakit kardiovaskular dan lainnya. Empat puluh tiga persen (43\%) dari 3,7 juta kematian ini terjadi sebelum usia 70 tahun. Persentase kematian yang disebabkan oleh diabetes yang terjadi sebelum usia 70 tahun lebih tinggi di Negara Negara berpenghasilan rendah dan menengah daripada di negara-negara berpenghasilan tinggi. (WHO Global Report, 2016).

Prevalensi Diabetes Mellitus semua umur di Indonesia pada Riskesdas 2018 sedikit lebih rendah dibandingkan prevalensi DM pada usia $\geq 15$ tahun, yaitu sebesar $1,5 \%$. Namun, Jika dibandingkan dengan tahun 2013, prevalensi DM berdasarkan diagnosis dokter pada penduduk umur $\geq 15$ tahun hasil Riskesdas 2018 meningkat menjadi 2\% (Kemenkes, 2018). Berdasarkan kategori usia, penderita DM terbesar berada pada rentangusia 55-64 tahun dan 65-74 tahun. Selain itu, penderita DM di Indonesia lebih banyakberjenis kelamin perempuan $(1,8 \%)$ daripada laki-laki $(1,2 \%)$. Kemudian untuk daerah domisili lebih banyak penderita diabetes melitus yang berada di perkotaan $(1,9 \%)$ dibandingkan dengan di perdesaan $(1,0 \%)$ (Kemenkes RI, 2018). Berdasarkan hasil dari beberapa penelitian yang telah dilakukan, terdapat hubungan antara tingkat pengetahuan dengan pengendalian kadar glukosa darah, diantaranya yaitu penelitian yang dilakukan oleh Jazilah (2003), Rahmadiliyani dan Muhlisin (2008), Kunaryanti, dkk (2018).

Pada tahun 2018 berdasarkan data Puskesmas Benda Baru diketahui bahwa penyakit Diabetes Mellitus merupakan peringkat kedua dari 10 besar penyakit yang diderita oleh warga di sekitar kelurahan Benda Baru Ciputat. Berdasarkan hasil observasi awal yang dilakukan di wilayah RW 004 Kelurahan Benda Baru diperoleh data bahwa 70\% penduduk memiliki pengetahuan yang rendah tentang Diabetes Mellitus. Dengan demikian, dibutuhkan 
edukasi berupa penyuluhan kesehatan untuk meningkatkan pengetahuan dan pemahaman penduduk terutama di wilayah RW 004 Kelurahan Benda Baru mengenai Diabetes Mellitus.

\section{METODE}

Metode yang digunakan dalam kegiatan pengabdian masyarakat di wilayah RW 004 Kelurahan Benda Baru adalah edukasi melalui penyuluhan kesehatan mengenai Diabetes Mellitus dalam bentuk ceramah dan diskusi. Pelaksanaan kegiatan penyuluhan kesehatan pada tanggal 09 Februari 2020. Peserta penyuluhan kesehatan adalah warga/penduduk di wilayah RW 004 Kelurahan Benda Baru. Untuk mengetahui terdapatnya peningkatan pengetahuan mengenai Diabetes Mellitus dilakukan pre test (sebelum penyuluhan) dan post test (sesudah penyuluhan) pada waktu yang samasaat penyuluhan kesehatan dilakukan dengan memberikan kuesioner berisi pertanyaan yang terkait Diabetes Mellitus sesuai dengan materi yang akan diberikan pada saat penyuluhan kesehatan.

\section{HASIL DAN PEMBAHASAN}

Kelurahan Benda Baru merupakan Kelurahan yang terletak di Kecamatan Pamulang Kota Tangerang Selatan yang memiliki jumlah total penduduk 31.487 jiwa, 24 RW dan 155 RT. Sedangkan di RW 004 terdapat 8 RT.

Kegiatan pengabdian masyarakat di RW 004 Kelurahan Benda Baru Kecamatan Pamulang Kota Tangerang Selatan dilakukan pada pagi hari pukul 08.00 WIB dengan dibantu oleh pihak Puskesmas dalam penyelenggaraannya. Sebelum kegiatan penyuluhan kesehatan dilaksanakan, pada pukul 06.30 WIB dilakukan senam bersama sebagai salah satu bantuk kegiatan dalam mengendalikan kadar gula darah.

Tabel 1. Distribusi Rata-Rata Skor Pengetahuan Menurut Pengukuran Pertama dan Pengukuran Kedua di RW. 004 Kelurahan Benda Baru Kecamatan Pamulang Kota Tangerang Selatan

\begin{tabular}{llll}
\hline \multicolumn{1}{c}{ Variabel } & \multicolumn{1}{c}{ Mean } & \multicolumn{1}{c}{ P Value } & N \\
\hline Pengetahuan & & & \\
Pengukuran I & 35,5 & 0,002 & 60 \\
Pengukuran II & 91,25 & & \\
\hline
\end{tabular}

Sumber: data primer, 2020

Berdasarkan tabel 1 diperoleh hasil dari pre dan post testbahwa terjadinya peningkatan pengetahuan antara sebelum dengan sesudah penyuluhan kesehatan. Rata-rata skor tingkat pengetahuan sebelum penyuluhan kesehatan sebesar 35,5, sedangkan sesudah penyuluhan kesehatan diperoleh skor sebesar 91,25.

Pada analisis bivariat dengan menggunakan uji t-dependent diperoleh hasil nilai $\mathrm{p}$ sebesar 0,002. Dengan demikian, dapat disimpulkan bahwa terdapatnya perbedaan yang signifikan tingkat pengetahuan antara sebelum dan sesudah penyuluhan kesehatan.

Notoadmodjo (2010) berpendapat bahwa salah satu faktor yang menentukan perilaku kesehatan seseorang adalah tingkat pengetahuan. Sehingga dapat dikatakan tingkat pengetahuan seseorang memiliki peranan yang sangat penting dalam berperilaku mengontrol kadar gula darah. Penelitian yang dilakukan oleh Nurul Alfiani, dkk (2017) menyatakan bahwa terdapat hubungan antara pengetahuan Diabetes Mellitus dengan gaya hidup pasien Diabetes Mellitus (p-value=0,000). Selain itu dalam penelitian yang dilakukan oleh Susanti, dkk (2018) menyatakan bahwa ada hubungan antara pola makan dengan kadar gula darah pada penderita Diabetes Mellitus (p-value=0,000). Sehingga dapat disimpulkan bahwa 
seseorang yang cenderung berperilaku sehat dengan menjaga pola makannya atau gaya hidupnyaakan memiliki kadar gula darah yang terkontrol dibandingkan dengan seseorang yang tidak menjaga perilaku sehatnya.

Hal ini dapat diperkuat dengan penelitian yang dilakukan oleh Jazilah (2003), Rahmadiliyani dan Muhlisin (2008), Kunaryanti, dkk (2018) menyatakan bahwa terdapat hubungan antara tingkat pengetahuan dengan pengendalian kadar glukosa darah. Dengan demikian, tingkat pengetahuan seseorang sangat mempengaruhi perilaku dalam mengendalikan kadar glukosa darah. Seseorang yang memiliki tingkat pengetahuan yang tinggi, akan cenderung mengendalikan kadar gula darahnya untuk kesehatannya dengan berperilaku sehat dibandingkan dengan seseorang yang memiliki tingkat pengetahuan yang rendah.

Selain penyuluhan kesehatan yang dilakukan di RW 004 Kelurahan Benda Baru Kecamatan Pamulang Kota Tangerang Selatan., diperkenalkan kalender KLG2 (Kontrol Lemak, Gula, dan Garam) sebagai media atau sarana untuk mengendalikan kadar gula darah dengan cara memantau konsumsi Lemak, Gula, dan Garam sehari-hari. Sebelum dilakukan pengisian kalender KLG2, dilakukan pengecekan kadar gula darah (pengukuran I). Setelah 2 minggu menggunakan kalender KLG2 dengan mencatat konsumsi Lemak, Gula, dan Garam sesuai yang dianjurkan untuk kesehatan, diukur kembali kadar gula darahnya (pengukuran II). Setelah dilakukan pengukuran kadar gula darah dengan jarak 2 minggu dari pengukuran yang pertama diperoleh hasil ada perbedaan kadar gula darah antara pengukuran I dengan Pengukuran ke II dengan nilai p sebesar 0,013.

\section{KESIMPULAN DAN SARAN}

Terdapat perbedaan tingkat pengetahuan antara sebelum dan sesudah dilakukan penyuluhan kesehatan mengenai Diabetes Mellitus. Selain itu, terdapat perbedaan kadar gula darah antara pengukuran I (sebelum menggunakan kalender KLG2) dengan pengukuran ke II (sesudah menggunakan kalender KLG2 dengan mencatat konsumsi Lemak, Gula, dan Garam per hari). Dengan demikian, Tingkat pengetahuan memiliki peranan yang sangat penting dalam mengubah perilaku seseorang. Seseorang yang memiliki pengetahuan tinggi cenderung akan menerapkan pola makan yang sehat (berperilaku sehat) dibandingkan dengan seseorang yang memiliki tingkat pengetahuan rendah. Sehingga diharapkan bagi institusi pelayanan kesehatan (Puskesmas Benda Baru) yang berada di sekitar wilayah Kelurahan Benda Baru untuk aktif memberikan edukasi berupa penyuluhan kesehatan kepada masyarakat secara berkala dalam rangka meningkatkan pengetahuan masyarakat mengenai penyakit Diabetes Mellitus dan aktif menggerakkan program kesehatan lainnya bersama masyarakat untuk mencegah Diabetes Mellitus dan megendalikan kadar gula darah.

\section{UCAPAN TERIMA KASIH}

Terima kasih kami ucapkan kepada pihak Puskesmas dan warga di RW 004 Kelurahan Benda Baru Kecamatan Pamulang Kota Tangerang Selatan yang telah memberikan kesempatan kepada kami untuk melakukan pengabdian masyarakat sebagai upaya untuk menciptakan masyarakat yang sehat.

\section{DAFTAR PUSTAKA}

Jazilah, 2003. Hubungan Tingkat Pengetahaun, Sikap dan Praktik (PSP) Penderita Diabetes Melitus Mengenai Pengelolaan Diabetes Melitusdengan Kendali Kadar Glukosa Darah. Tesis Megister Ilmu Kesehatan (Gizi dan Kesehatan). Pascasarjana UniversitasGajah Mada, Yogyakarta. 
Kementerian Kesehatan RI. 2018. Pusat Data dan Informasi Kementerian Kesehatan RI. Kemenkes Repulik Indonesia

Kunaryanti, Annisa A, dan Riyani W. 2018. Hubungan Tingkat Pengetahuan Tentang Diabetes Mellitus Dengan Perilaku Mengontrol Gula Darah Pada Pasien Diabetes Mellitus Rawat Jalan Di RSUD Dr. Moewardi Surakarta. Jurnal Kesehatan. Vol. 11, No. 1

Notoadmodjo, 2010. Metodologi Penelitian Kesehatan. Jakarta; Penerbit Rineka Cipta.

Nurul Alfiani dkk. (2017). Hubungan Pengetahuan Diabetes Melitus Dengan Aya Hidup Pasien Diabetes Melitus Di Rumah Sakit Tingkat II dr. SOEPRAOEN MALANG . Nursing News, 390-402.

Rahmadiliyani N., Muhlisin A., 2008. Hubungan Antara Pengetahuan Tentang Penyakit DanKomplikasi Pada Penderita Diabetes MelitusDengan Tindakan Mengontrol Kadar GulaDarah Di Wilayah Kerja Puskesmas I Gatak Sukoharjo. Jurnal Ilmu KeperawatanUniversitas Muhammadiyah Surakarta. 1: 63-7.

Kementerian Kesehatan Republik Indonesia. 2018. Riset Kesehatan Dasar (Riskesdas) 2018.

Badan Penelitian dan Pengembangan Kesehatan Kementerian RI

Susanti dkk. (2018). Hubungan Pola Makan Dengan Kadar Gula Darah Pada Penderita Diabetes Mellitus. Jurnal Kesehatan Vokasional, 29-34.

World Health Organization (WHO), 2016. WHO Global Report 2016.

World Health Organization (WHO), 2018. WHO Global Report 2018. 